\title{
Relation between structure and low-temperature geothermal systems in Fukuoka city, southwestern Japan
}

\author{
Hakim Saibi $^{1}$, Jun Nishijima ${ }^{1}$, Tomohiro Hirano ${ }^{2}$, Yasuhiro Fujimitsu ${ }^{1}$, and Sachio Ehara ${ }^{1}$ \\ ${ }^{1}$ Laboratory of Geothermics, Department of Earth Resources Engineering, Faculty of Engineering, Kyushu University, \\ 744 Motooka, Nishi-ku, Fukuoka 819-0395, Japan \\ ${ }^{2}$ Laboratory of Geothermics, Graduate School of Engineering, Kyushu University, 744 Motooka, Nishi-ku, Fukuoka 819-0395, Japan
}

(Received February 8, 2008; Revised April 25, 2008; Accepted April 28, 2008; Online published September 8, 2008)

\begin{abstract}
The Fukuoka area is located in the southwestern part of Japan. The Yokote-Ijiri area, located in the southern part of Fukuoka city, has several low-temperature geothermal systems, including eleven hot springs. From 1996 to 2008, the Fukuoka area was investigated by gravity survey, using Scintrex CG-3 and CG-3M gravimeters, in an attempt to delineate its subsurface structure. The surveys were intended to improve the understanding of the relation between the geothermal systems and the subsurface structure as well as to locate the active faults in the surveyed area, which are responsible for generating large earthquakes. The gravity data were analyzed using integrated gradient interpretation techniques, such as the Horizontal Gradient (HG), Tilt Derivative (TDR), and Euler deconvolution methods. With these techniques, many faults were detected, including the famous Kego fault, which is an active fault in Fukuoka city. A 2-D gravity model was constructed to show the relationship between the faults and the geothermal systems. The results of the present study will hopefully lead to an understanding of the relationships between the interpreted faults and the location of the low-temperature geothermal systems and possibly aid in future geothermal exploration of the area.
\end{abstract}

Key words: Gravity, Fukuoka city, Kego fault, low-temperature geothermal systems, structure.

\section{Introduction}

Several low-temperature hot springs are located in the Yokote-Ijiri area of the southern part of Fukuoka city. Fujimitsu et al. (2003) stated that the hot springs were likely generated by a specific subsurface structure of unknown origin. Karakida et al. (1994) suggested that an active fault, named the Kego fault, passes through the Yokote-Ijiri area, but no scientific investigations have been conducted to locate the Kego fault.

Therefore, the aim of this study is to delineate the subsurface structure of the Fukuoka area and to determine its relationship with low-temperature geothermal systems by applying gradient interpretation methods to the available gravity data.

The studied area was struck by a strong earthquake on March 20, 2005 ( $\left.M_{\mathrm{JMA}} 7.0\right)$ at a depth of $9 \mathrm{~km}$, which was followed by a $M_{\text {JMA }} 5.8$ aftershock on April 20. Many scientists believed that the earthquake occurred along the extension of the Kego fault, which runs from the northwest to the southeast under the Sea of Genkai. The results of the present study will delineate the boundaries of the Kego fault, which is of interest to those studying the seismology of the area.
Copyright (c) The Society of Geomagnetism and Earth, Planetary and Space Sciences (SGEPSS); The Seismological Society of Japan; The Volcanological Society of Japan; The Geodetic Society of Japan; The Japanese Society for Planetary Sciences; TERRAPUB

\section{Gravity Data}

The Fukuoka area is located in the southwestern part of Japan, between the $33^{\circ} 32^{\prime}-33^{\circ} 42^{\prime} \mathrm{N}$ latitude and the $130^{\circ} 17^{\prime}-130^{\circ} 28^{\prime} \mathrm{E}$ longitude (Fig. 1) lines. Geologically, the Fukuoka area is composed of Paleozoic Sangun metamorphic rocks, Late Mesozoic granitic rocks, Paleogene and Neogene basaltic rocks, and Quaternary sediments (Matsushita et al., 1971; Karakida et al., 1994). The basement rock consists mostly of granite (Matsushita et al., 1971).

The Fukuoka area was investigated by gravity surveys between 1996 and 2008 using Scintrex CG-3 and CG-3M gravimeters, extending over an area of $315 \mathrm{~km}^{2}$. The gravity data set, consisting of Bouguer gravity data from 1797 stations (Geological Survey of Japan, 2000: 49 stations; Geographical Survey Institute, 2008: 8 stations; Geothermics Laboratory of Kyushu University: 1740 stations) with a spacing between $50 \mathrm{~m}$ and $2 \mathrm{~km}$, was analyzed using integrated gradient interpretation techniques. In this study, the gravity data are used to delineate the subsurface structure of the Fukuoka area. The Bouguer anomaly map of the study area was derived at a density of $2470 \mathrm{~kg} / \mathrm{m}^{3}$ (Hirano et al., 2006), as shown in Fig. 2(A). The area is characterized by positive gravity values, which cover the entire area and range between 15.6 and $40.9 \mathrm{mGal}$, increasing in the northern and western regions of the map area. Two low Bouguer gravity anomalies can be seen in the central part of the area extending in the NW-SE direction. The hot springs are located at the border between very-low and low Bouguer gravity anomalies (Fig. 2(B)). This region may re- 


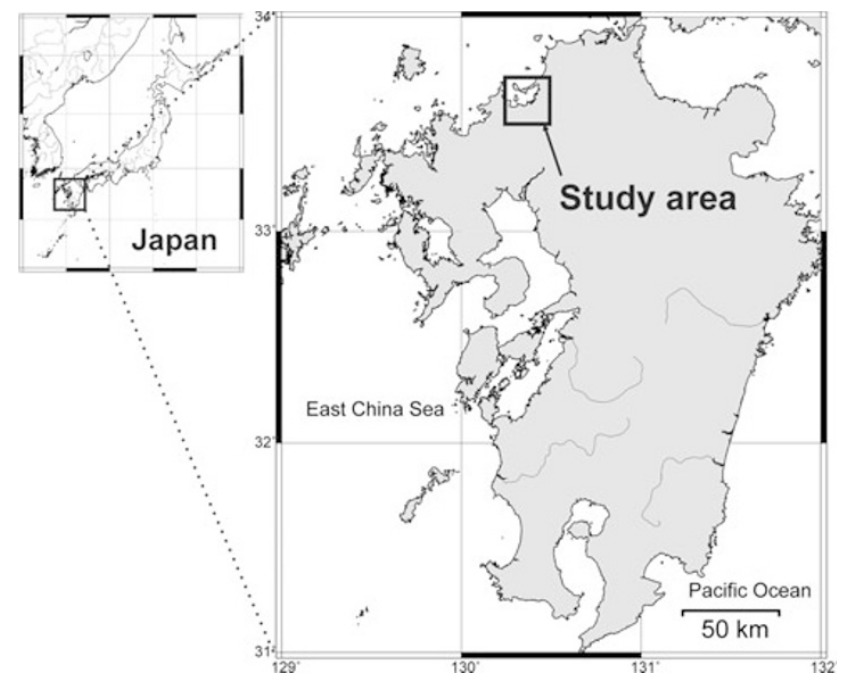

Fig. 1. Location of the Fukuoka area in Kyushu Island, Japan.

(A)

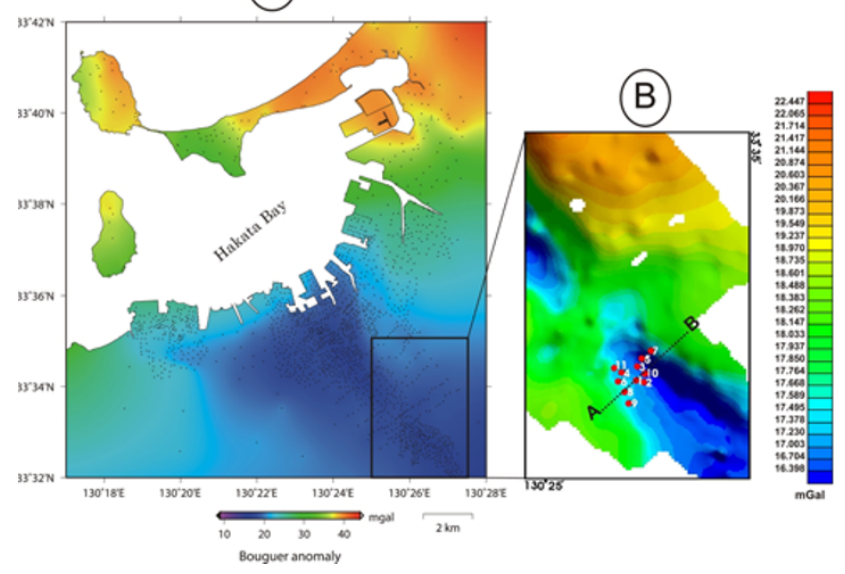

Fig. 2. (A) Bouguer gravity map of the Fukuoka area. Black points indicate the locations of the gravity stations. The black rectangle indicates the area of Figs. 5, 6, 7, and 9. (B) The hot spring location is overlapped on the Bouguer gravity map.

flect a small basin elongated in the NW-SE direction.

Based on petrographic and macroscopic analysis of drill cuttings and core samples (Matsushita et al., 1971), the stratigraphic column of Yokote-Ijiri, in the southern part of Fukuoka city, can be divided into three layers. Layer 1 consists of gravel and sand, layer 2 consists of weathered granite, and layer 3 corresponds to the Mesozoic granite that represents the basement rock in this area (Fig. 3). Layer 1 is absent in well No. 1. Paleogene sandstone was encountered at the bottom of well No. 10, beneath a fracture zone. Matsushita et al. (1971) explained this as an overturned structure in the area. This fracture zone is believed to represent the Kego fault.

\section{Methodology}

In our study, three gravity interpretation techniques were used: HG, TDR, and Euler deconvolution. The combination of the three methods enhanced the structural definition of the study area. The TDR method has the advantage of

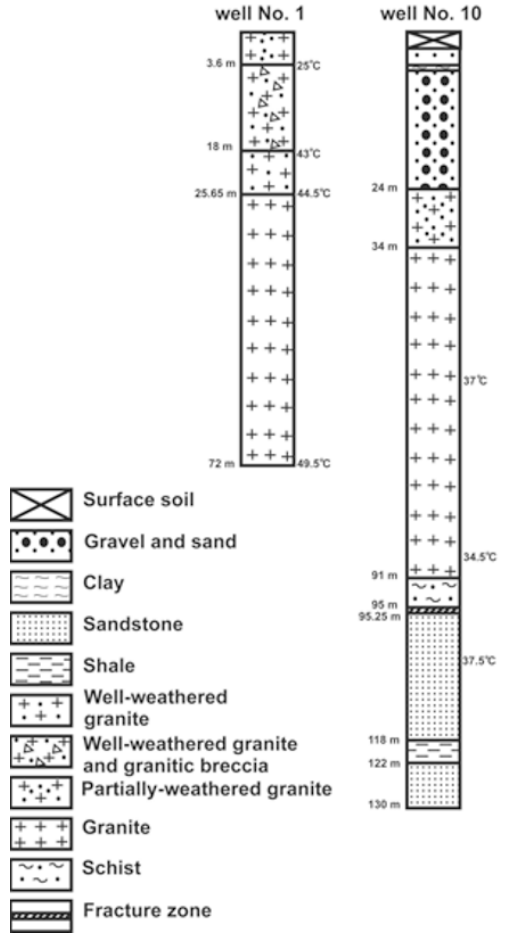

Fig. 3. Stratigraphic log of two drill-holes (wells 1 and 10) in the Yokote-Ijiri area (Matsushita et al., 1971). The two drill-holes are used as control points in the forward gravity modeling (see Fig. 10).

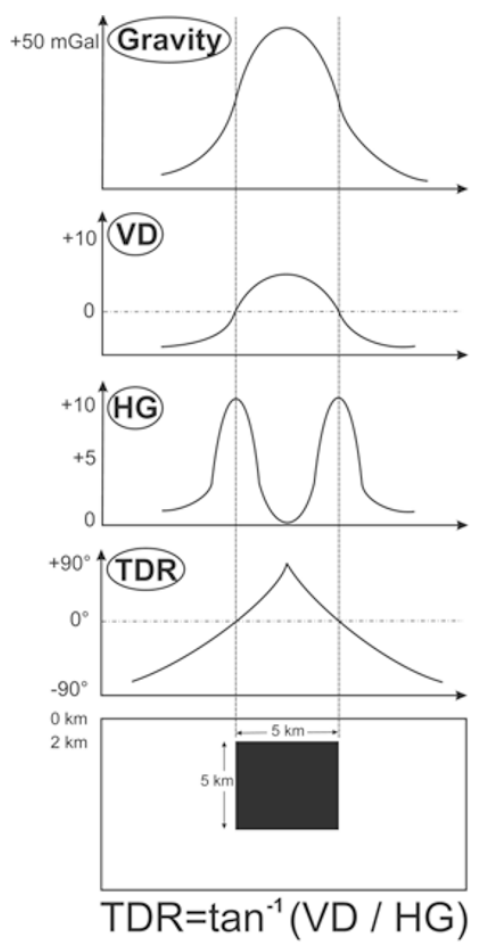

Fig. 4. Gravity anomaly (mGal) over one block. Density contrast is $1000 \mathrm{~kg} / \mathrm{m}^{3}$. TDR $=$ Tilt angles (degrees), $\mathrm{HG}=$ Horizontal Gradient $(\mathrm{mGal} / \mathrm{m}), \mathrm{VD}=$ Vertical Derivative $(\mathrm{mGal} / \mathrm{m})$.

responding well to both shallow and deep sources, and the map of TDR recognizes the horizontal location and extent of sources. The location of the maximum HG may be used as an indicator of the locations of edges of the source. The 
Euler solutions give the depths of the sources. The HG and TDR techniques are illustrated in Fig. 4.

\section{Horizontal Gradient of Gravity Data}

The horizontal gradient method was used extensively to locate the boundaries of density contrast from gravity data or pseudogravity data. The method contends that the horizontal gradient of the gravity anomaly caused by a tabular body tends to overlie the edges of the body if the edges are vertical and well separated from each other (Cordell, 1979; Cordell and Grauch, 1985).

The greatest advantage of the horizontal gradient method is that it is least susceptible to noise in the data because it requires only the calculation of the two first-order horizontal derivatives of the field (Phillips, 1998). The method is also robust in delineating both shallow and deep sources, in comparison with the vertical gradient method, which is useful only in identifying shallower structures. The amplitude of the horizontal gradient (Cordell and Grauch, 1985) is expressed as:

$$
\mathrm{HG}_{\mathrm{g}}=\sqrt{\left(\frac{\partial g}{\partial x}\right)^{2}+\left(\frac{\partial g}{\partial y}\right)^{2}}
$$

where $(\partial g / \partial x)$ and $(\partial g / \partial y)$ are the horizontal derivatives of the gravity field in the $x$ and $y$ directions, respectively. The amplitude of the horizontal gradient in the Fukuoka area was calculated in the frequency domain and is illustrated in Fig. 5. The area may be dissected by major faults striking in the N-S and NW-SE directions.

\section{Tilt Derivative of Gravity Data}

The TDR method was used to enhance and sharpen the potential field anomalies. The advantage of TDR is that it can show the zero contour line located on or close to a contact. The TDR is calculated by the following formula (Miller and Singh, 1994):

$$
\begin{aligned}
\text { Tilt } & =\tan ^{-1} \frac{\text { vertical component of gradient }}{\text { horizontal component of gradient }} \\
& =\tan ^{-1} \frac{\frac{\partial g}{\partial z}}{\sqrt{\left(\frac{\partial g}{\partial x}\right)^{2}+\left(\frac{\partial g}{\partial y}\right)^{2}}} .
\end{aligned}
$$

The TDR results are presented in Fig. 6.

\section{Euler Deconvolution of Gravity Data}

Euler deconvolution was used to estimate the depth and location of gravity source anomalies. The method was established by Thompson (1982) and applied to magnetic data along profiles. Reid et al. (1990), following a suggestion in Thompson's paper, developed an equivalent method to operate on gridded magnetic data. The application of Euler deconvolution to gravity data has been carried out by several authors, including Wilsher (1987), Corner and Wilsher (1989), Klingele et al. (1991), Marson and Klingele (1993), Fairhead et al. (1994), and Huang et al. (1995).

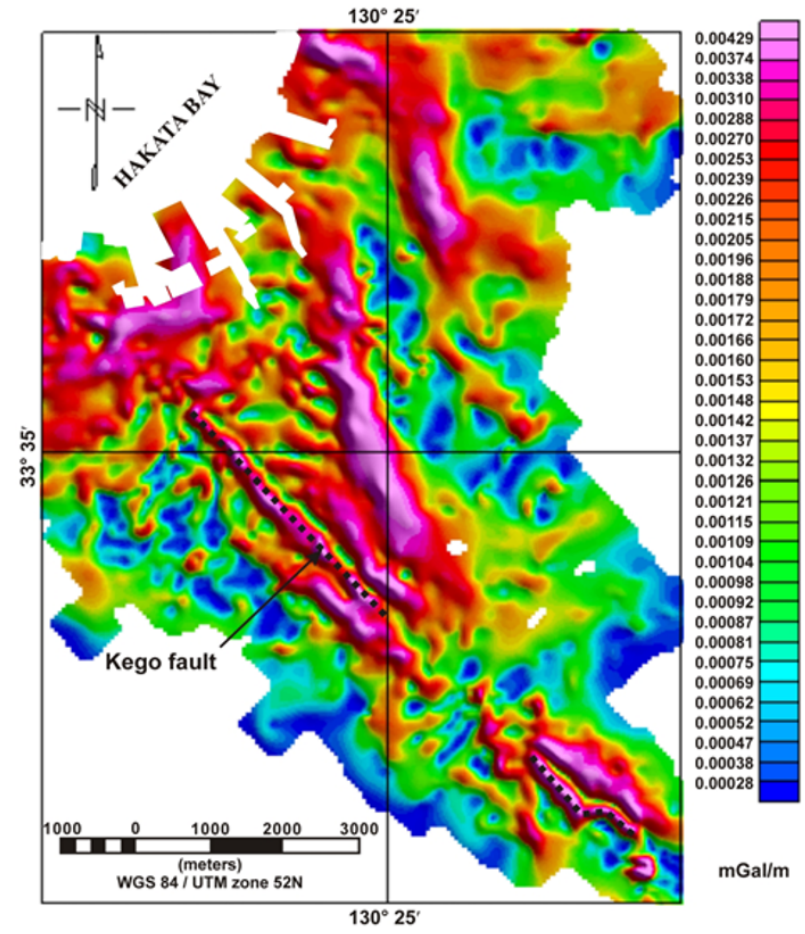

Fig. 5. Horizontal gradient map of gravity data.

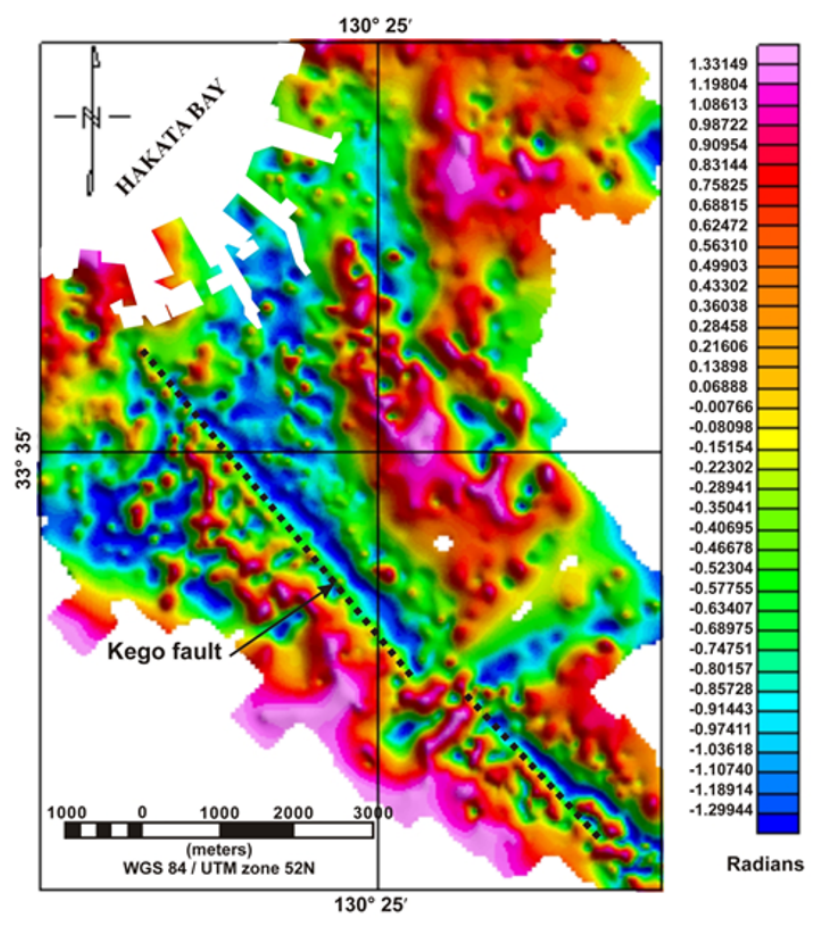

Fig. 6. Tilt derivative of gravity data. The zero value matches well with the HG map of gravity data.

The 3D equation for Euler deconvolution given by Reid et al. (1990) is

$$
\left(x-x_{\mathrm{o}}\right) \frac{\partial g}{\partial x}+\left(y-y_{\mathrm{o}}\right) \frac{\partial g}{\partial y}+\left(z-z_{\mathrm{o}}\right) \frac{\partial g}{\partial z}=\eta(\beta-g) .
$$

Equation (3) can be rewritten as

$x \frac{\partial g}{\partial x}+y \frac{\partial g}{\partial y}+z \frac{\partial g}{\partial z}+\eta g=x_{\mathrm{o}} \frac{\partial g}{\partial x}+y_{\mathrm{o}} \frac{\partial g}{\partial y}+z_{\mathrm{o}} \frac{\partial g}{\partial z}+\eta \beta$, 
Table 1. Characteristics of hot spring waters in the Fukuoka area (Matsushita et al., 1971).

\begin{tabular}{cccc}
\hline Well number & Temperature in ${ }^{\circ} \mathbf{C}$ & Depth in meter & Amount in $1 / \mathrm{min}$. \\
\hline 1 & 49 & 72 & 100 \\
2 & 43 & 70 & 54.6 \\
3 & 37.5 & 100 & 120 \\
4 & 46 & 78 & 50 \\
5 & 31 & 100 & 26 \\
6 & 42 & 150 & 110 \\
7 & 27 & 100 & 20 \\
8 & 46 & 150 & 120 \\
9 & 34.3 & 150 & 41 \\
10 & 33.1 & 130 & 34.2 \\
11 & 43 & 100 & 120 \\
\hline
\end{tabular}
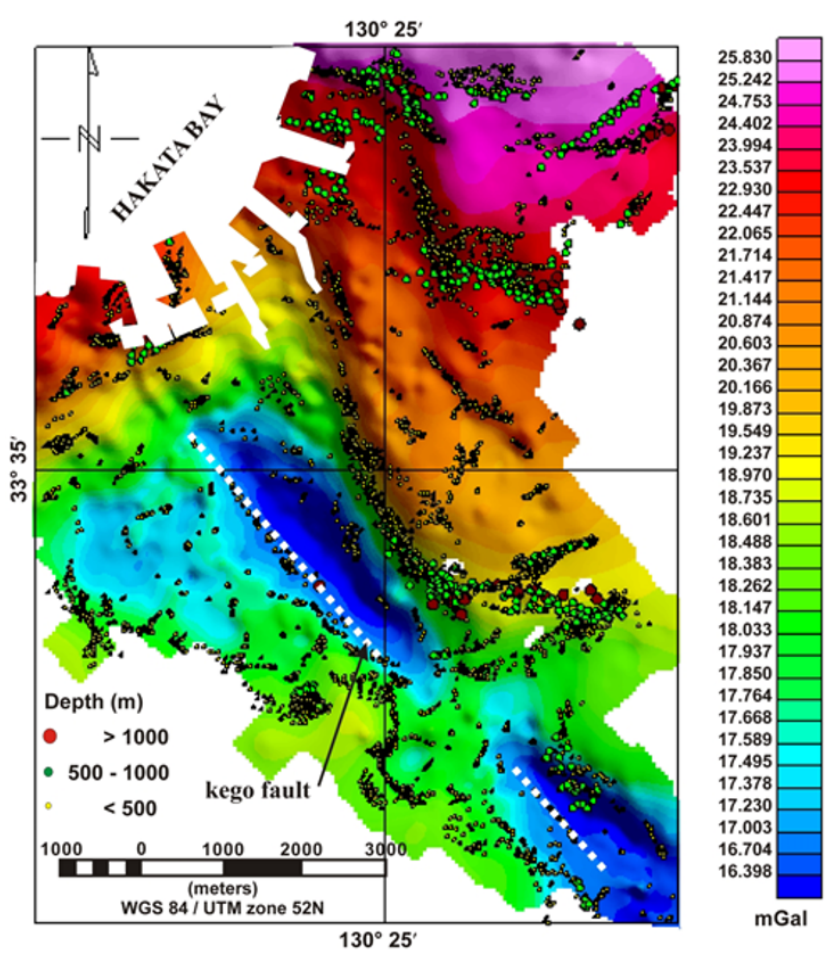

Fig. 7. Euler solutions for a structural index of zero. The maximum relative error is $10 \%$. Solutions were selected using standard criteria. The solutions of the Euler deconvolution are consistent with the results of TDR and HG. The background is the image of the Bouguer gravity map. The depth of the Kego fault is less than $500 \mathrm{~m}$, as shown by the good clustering of the Euler solutions.

where $\left(x_{\mathrm{o}}, y_{\mathrm{o}}, z_{\mathrm{o}}\right)$ is the position of a source whose total gravity is detected at $(x, y, z), \beta$ is the regional value of the gravity, and $\eta$ is the structural index (SI), which can be defined as the rate of attenuation of the anomaly with distance. SI must be chosen according to prior knowledge of the source geometry. For example, SI $=2$ for a sphere, $\mathrm{SI}=1$ for a horizontal cylinder, SI $=0$ for a fault, and $\mathrm{SI}=-1$ for a contact (FitzGerald et al., 2004). The two horizontal gradients $(\partial g / \partial x, \partial g / \partial y)$ and the vertical gradient $(\partial g / \partial z)$ are used to compute the anomalous source locations.

By considering four or more neighboring observations at a time (an operating window), both the source location $\left(x_{\mathrm{o}}\right.$, $y_{\mathrm{o}}, z_{\mathrm{o}}$ ) and $\beta$ can be computed by solving a linear system of equations generated from Eq. (4). Then, by moving the operating window from one location to the next over the anomaly, multiple solutions for the same source are obtained. In our study, Euler deconvolution was applied to the gravity data using a moving window of $250 \mathrm{~m} \times$ $250 \mathrm{~m}$. The grid cell size was $500 \mathrm{~m}$. We assigned several structural index values and found that an SI of zero gave good clustering solutions. Reid et al. (1990, 2003), and Reid (2003) presented a structural index equal to zero for the gravity field for detecting faults. The results of the Euler deconvolution for the gravity data are shown in Fig. 7.

The interpretation of the Euler solutions (Fig. 7) indicates that NE-SW, NW-SE, E-W, and N-S trends characterize the structural setting of the Fukuoka area. The depths of the faults range from less than $500 \mathrm{~m}$ to more than $1000 \mathrm{~m}$.

\section{Discussion and Conclusion}

Eleven hot springs were detected in the Fukuoka area. These low-temperature hot springs are located in the Yokote-Ijiri area in the southern part of Fukuoka city. The generation of the hot springs in this area is not related to a specific heat source (Karakida et al., 1994). Moreover, the hot springs area is characterized by low resistivity (less than $10 \Omega \mathrm{m}$ ), which is explained by the low resistivity of hot water (Matsushita et al., 1971). Fujimitsu et al. (2003) showed that the high temperature distribution of the hot springs in the Yokote-Ijiri area extends in the NW-SE direction (Fig. 8). The hot springs are located in a dense fractured area, and their characteristics are described in Table 1. The hottest hot spring was well No. 1 , at $49^{\circ} \mathrm{C}$.

Figure 9 shows a qualitative interpretation of the horizontal gradient data and the tilt derivative data. The Euler deconvolution method provided the depths of the faults; however, the HG and TDR methods yielded the precise locations of the faults. The results show a relation between the structural pattern and the locations of the hot springs in the Fukuoka area. A rose diagram (Fig. 9) indicates that there are four major fault patterns (N-S, E-W, NE-SW, NW-SE) that characterize the study area. The Fukuoka area is dissected by major faults striking in the E-W and NW-SE directions. The depth of these faults is less than $500 \mathrm{~m}$, which was determined from the Euler deconvolution method. The faults located on the eastern side of the hot springs are deeper than the faults on the western side, and hot spring waters are seen to emerge along fault lineaments. 
Table 2. Statistical analysis of the interpreted lineaments in the Fukuoka area. The total number of lineaments is 112 . Using the count of the number of lineaments, we have two main groups: the first group (11 lineaments), in the direction of $-40^{\circ} \mathrm{W}$; and the second group (11 lineaments), in the direction of $90^{\circ} \mathrm{E}$. The first group has a long length, while the second group has a short length. The maximum length reaches $-30^{\circ} \mathrm{W}(2421 \mathrm{~m})$, while the shortest lineament is observed at $60^{\circ} \mathrm{E}(648 \mathrm{~m})$.

\begin{tabular}{|c|c|c|c|c|c|c|}
\hline $\begin{array}{c}\text { Angle } \\
\text { (degree) }\end{array}$ & $\begin{array}{l}\text { Number of } \\
\text { lineaments }\end{array}$ & $\begin{array}{l}\text { Minimum length } \\
\text { (m) }\end{array}$ & $\begin{array}{l}\text { Maximum length } \\
\text { (m) }\end{array}$ & $\begin{array}{l}\text { Mean length } \\
\text { (m) }\end{array}$ & $\begin{array}{c}\text { Total length } \\
\text { (m) }\end{array}$ & $\begin{array}{c}\text { Mean angle } \\
\text { (degree) }\end{array}$ \\
\hline-80 & 5 & 194.41 & 840.29 & 560.14 & 2800.72 & -78.8 \\
\hline-70 & 7 & 192.58 & 1579.5 & 858.8 & 6011.57 & -70.6 \\
\hline-60 & 8 & 261.19 & 1019.5 & 541.77 & 4334.18 & -58.5 \\
\hline-50 & 10 & 316.4 & 2315.41 & 922.46 & 9224.6 & -50.5 \\
\hline-40 & 11 & 387.83 & 2169.53 & 1003.11 & 11034.2 & -40.9 \\
\hline-30 & 5 & 286.71 & 2421.49 & 1041.38 & 5206.88 & -30.7 \\
\hline-20 & 9 & 208.18 & 1355.82 & 682.96 & 6146.65 & -21.4 \\
\hline-10 & 6 & 223.17 & 2236.61 & 880.24 & 5281.45 & -11.7 \\
\hline 0 & 7 & 228.21 & 1580.04 & 666.68 & 4666.75 & -2 \\
\hline 10 & 8 & 349.27 & 705.73 & 531.95 & 4255.58 & 7.8 \\
\hline 20 & 4 & 213.24 & 922.29 & 554.79 & 2219.16 & 22.4 \\
\hline 30 & 3 & 303.91 & 863.27 & 562.63 & 1687.88 & 29.6 \\
\hline 40 & 4 & 238.41 & 1442.43 & 714.12 & 2856.48 & 41.6 \\
\hline 50 & 4 & 271.44 & 1361.05 & 839.73 & 3358.93 & 53.5 \\
\hline 60 & 1 & 648.54 & 648.54 & 648.54 & 648.54 & 62.1 \\
\hline 70 & 2 & 184.09 & 665.25 & 424.67 & 849.35 & 70.9 \\
\hline 80 & 7 & 170.47 & 1213.9 & 575.83 & 4030.81 & 79.9 \\
\hline 90 & 11 & 118.31 & 1433.1 & 528.15 & 5809.62 & 88.5 \\
\hline All lineaments & 112 & 118.31 & 2421.49 & 718.07 & 80423.34 & \\
\hline
\end{tabular}

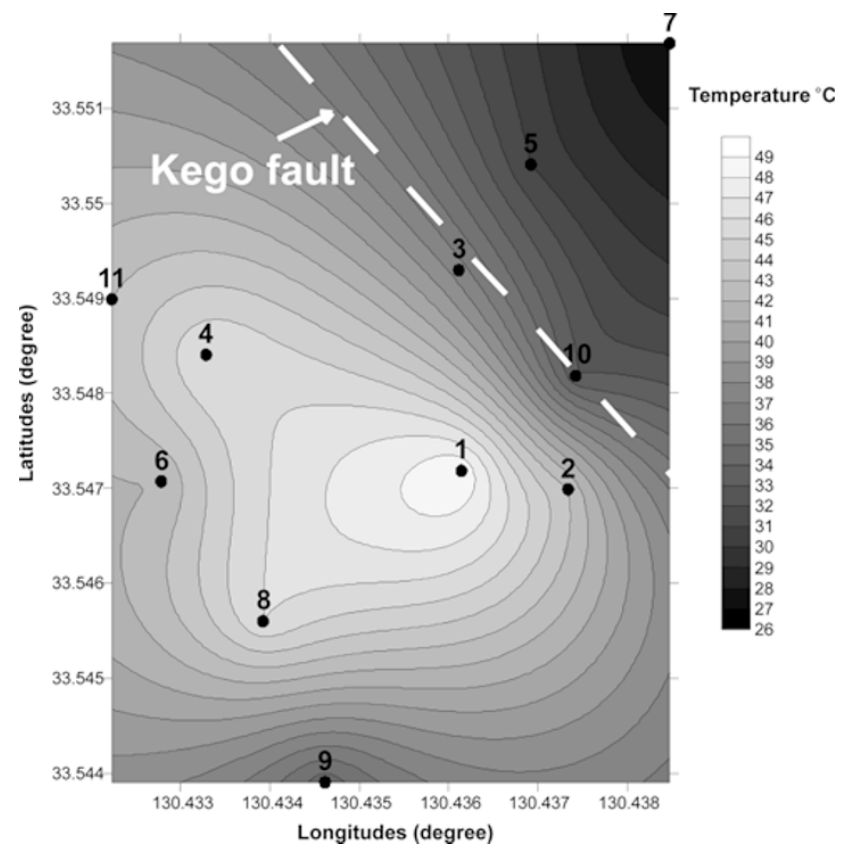

Fig. 8. Hot spring temperature distribution. Numbers are hot springs.

The interpreted faults were digitally processed and statistically analyzed using ER Mapper software version 7.0. ER Mapper provides a function that analyzes the orientation and distribution of the faults. The results are shown in Table 2 and provide important information about the tectonic setting of the study area:

1) Generally, the faults striking NW-SE have long lengths (maximum length of $2420 \mathrm{~m}$ ), while the faults striking E-W have shorter lengths. From the cross-cutting rela-

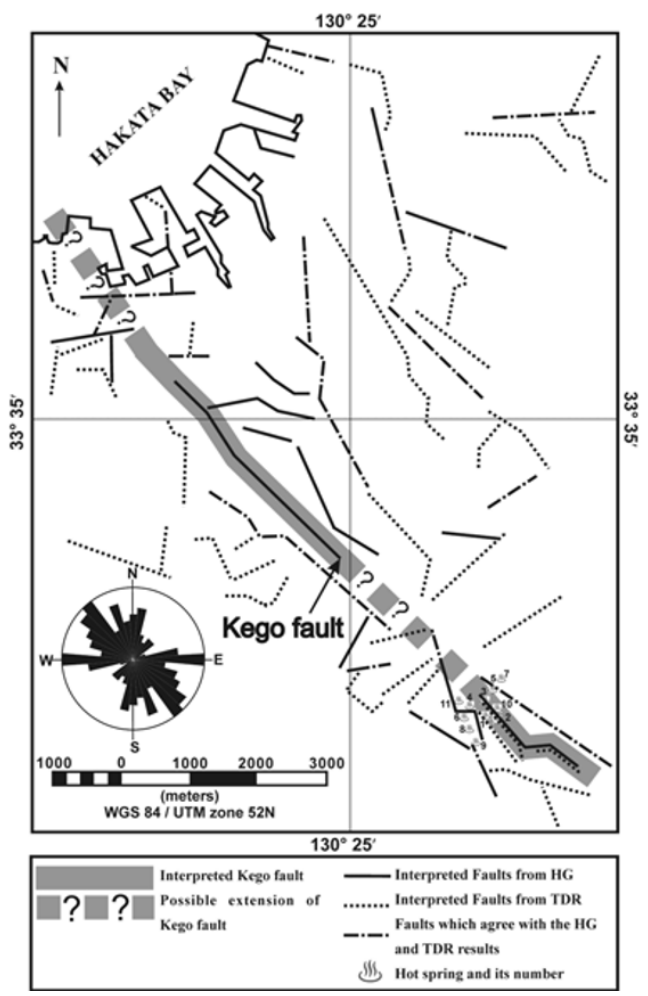

Fig. 9. Fault interpretation map of the Fukuoka area from the HG and TDR maps. Eleven hot springs are plotted as numbered. A rose diagram of faults extracted from the gravity data from the Fukuoka area is presented.

tionships, the faults striking NW-SE are younger than the E-W faults. In general, the new faults cut the older faults (Warvelle, 1968, page 23).

2) Many of the NW-SE striking faults show a 10 degree 


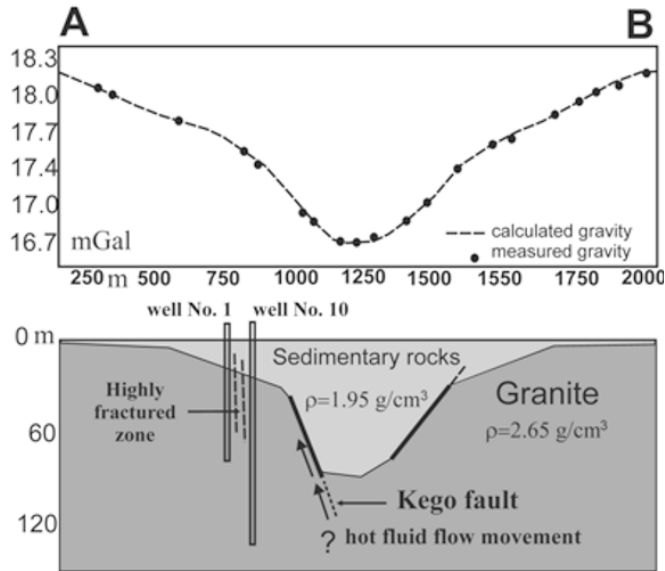

Fig. 10. 2-D model, using two wells (Nos. 1 and 10, see Fig. 2(B)) as control points, based on forward modeling of the gravity data using Talwani's algorithm (Talwani et al., 1959). The hot water flows up to the surface through the fault structure. The Kego fault could be the main flow path of the geothermal fluids. The density of the granite is assumed to be $2650 \mathrm{~kg} / \mathrm{m}^{3}$ and the sedimentary layer is $1950 \mathrm{~kg} / \mathrm{m}^{3}$.

shift towards the north or west due to tectonic reactivation.

3) The NW-SE striking faults are tectonically reactivated. This can be observed by recent earthquakes that have occurred in this area, caused mainly by the Kego fault.

Figure 10 shows a 2-D model line through points A and B (Fig. 2(B)). Two geological layers are included in the model using data from wells No. 1 and No. 10. The density of the two layers is taken from data from the Geological Survey Enterprises Association Kyushu (1981).

The model shows a basin $90 \mathrm{~m}$ deep, bordered by faults. The locations and depths of the faults agree with the results of the HG, TDR, and Euler deconvolution methods. The hot waters flow to the surface through the faults. The Kego fault may be the main flow path of the geothermal waters.

The obtained structural map is suitable for planning geothermal research in the Fukuoka area.

Acknowledgments. The first author acknowledges the financial support of the Japan Society for the Promotion of Science (JSPS) for research activities in Japan. The authors greatly appreciate the constructive and thoughtful comments of the two anonymous reviewers. We also thank Dr. Akira Takada (Geological Survey of Japan, AIST, Tsukuba), EPS editor for his comments and suggestions. This study is supported by KAKENHI (Grant-in-Aid for Exploratory Research by JSPS) No. 17651100 (Principal Researcher: Yasuhiro Fujimitsu).

\section{References}

Cordell, L., Gravimetric expression of graben faulting in Santa Fe Country and the Espanola Basin, New Mexico, in Guidebook to Santa Fe Country, 30th Field Conference, edited by R. V. Ingersoll, New Mexico Geological Survey, pp. 59-64, 1979.

Cordell, L. and V. J. S. Grauch, Mapping basement magnetization zones from aeromagnetic data in the San Juan Basin, New Mexico, in The utility of regional gravity and magnetic anomaly maps, edited by W. J. Hinz, Soc. Explor. Geophys., 181-197, 1985.

Corner, B. and W. A. Wilsher, Structure of the Witwatersrand basin derived from interpretation of the aeromagnetic and gravity data, in Proceedings of exploration '87, third decennial international conference on geophysical and geochemical exploration for minerals and groundwater, edited by G. D. Garland, Ontario Geol. Survey. Special, 3, 532-546, 1989.

Fairhead, J. D., K. J. Bennet, R. H. Gordon, and D. Huang, Euler: Beyond the 'Black Box', 64th Ann. Internat. Mtg., Soc. Expl. Geophys., Expanded Abstracts, 422-424, 1994.

FitzGerald, D., A. Reid, and P. McInerney, New discrimination techniques for Euler deconvolution, Comput. Geosci., 30, 461-469, 2004.

Fujimitsu, Y., J. Nishijima, Y. Oba, and S. Ehara, Low temperature hydrothermal system in the southern area of Fukuoka city, Japan, Proceedings of the 38th Conference of Société Internationale des Techniques Hydrothermales and the 56th Annual Meeting of the Balneological Society of Japan, Beppu, Japan, 2003.

Geographical Survey Institute, http://www.gsi.go.jp/ENGLISH/, 2008.

Geological Survey Enterprises Association, Kyushu, Fukuoka Jibanzu, Geotechnical data of subsoil in Fukuoka, 1981 (in Japanese).

Geological Survey of Japan (ed.), Gravity CD-ROM of Japan, Digital Geoscience Map P-2, Geological Survey of Japan, 2000.

Hirano, T., J. Nishijima, and Y. Fujimitsu, Estimation of fault structure using densed gravity survey data at Fukuoka city, Geothermal and Volcanological Research Report of Kyushu University, 15, 16-22, 2006.

Huang, D., D. Gubbins, R. A. Clark, and K. A. Whaler, Combined study of Euler's homogeneity equation for gravity and magnetic field, 57th Conf. \& Tech. Exhib., Euro. Assoc., Expl. Geophys, Extended Abstracts, 144, 1995.

Karakida, Y., S. Tomita, S. Shimoyama, and K. Chijiwa, Geology of the Fukuoka district, Quadrangle series, Scale 1:50000, Fukuoka (14) No. 51, 1-192, 1994 (in Japanese with English abstract).

Klingele, E. E., I. Marson, and H. G. Kahle, Automatic interpretation of gravity gradiometric data in two dimensions: vertical gradient, Geophys. Prospect., 39, 407-434, 1991.

Marson, I. and E. E. Klingele, Advantages of using the vertical gradient of gravity for 3-D interpretation, Geophys., 58(11), 1588-1595, 1993.

Matsushita, H., T. Miki, and A. Yamashita, An overturned structure observed in the southern part of Fukuoka city, The Science reports of the Shimabara Volcano Observatory, the Faculty of Science, Kyushu University, No. 7, 1-8, 1971 (in Japanese with English abstract).

Miller, H. G. and V. Singh, Potential field tilt-a new concept for location potential field sources, J. Appl. Geophys., 32, 213-217, 1994.

Phillips, J. D., Processing and interpretation of aeromagnetic data for the Santa Cruz Basin-Patahonia Mountains area, South-Central Arizona, U. S., Geological Survey Open-File Report 02-98, 1998.

Reid, A. B., Short note, Euler magnetic structural index of a thin bed fault, Geophys., Published electronically, 2003.

Reid, A. B., J. M. Allsop, H. Granser, A. J. Millet, and I. W. Somerton, Magnetic interpretation in three dimensions using Euler deconvolution, Geophys., 55, 80-91, 1990.

Reid, A., D. FitzGerald, and P. McInerney, Euler deconvolution of gravity data, SEG annual meeting, Dallas, 2003.

Talwani, M., J. L. Worzel, and M. Landisman, Rapid gravity computations for two-dimensional bodies with applications to the Mendocino submarine fracture zone, J. Geophys. Res., 64, 49-59, 1959.

Thompson, D. T., EULDPH-A new technique for making computerassisted depth estimates from magnetic data, Geophys., 47, 31-37, 1982.

Warvelle, J., Stratigraphy and geologic time, edited by W. C. Brown Co, 113 pp., 1968.

Wilsher, W. A., A structural interpretation of the Witwatersrand basin through the application of the automated depth algorithms to both gravity and aeromagnetic data, M.Sc. thesis, Univ. of Witwatersrand, 1987.

H. Saibi (e-mail: saibi-hakim@mine.kyushu-u.ac.jp), J. Nishijima, T. Hirano, Y. Fujimitsu, and S. Ehara 